\title{
ASPEK YANG MEMPENGARUHI PERSEPSI MODE FASHION KOMUNITAS URBAN DARI SISI ERGONOMI
}

\author{
Putu Hari Kurniawan*1, Rikson Pandapotan Tampubolon ${ }^{2}$, Yan Mahesa Damanik ${ }^{3}$ \\ $1,2,3$; Program Studi Manajemen Universitas Putera batam, \\ 1,2,3 Program Studi Teknik Industri Universitas Putera Batam \\ e-mail: ${ }^{* 1}$ harifebby@gmail.com, ${ }^{2}$ pandapotan@gmail.com, ${ }^{3}$ mahesaon@gmail.com
}

\begin{abstract}
Abstrak
Tujuan penelitian adalah untuk mengivestigasi permasalahan tentang eksistensi mode pakaian yang segmentasinya semakin meningkat belakangan ini. Peningkatan jumlah konsumen dan pengguna yang mencari produk yang berbeda dan sesuai dengan kebutuhan dan harapan mereka berdampak pada tahap desain serta pada proses manufaktur yang konsisten. Dengan demikian pemahaman segmentasi konsumen dan pengguna yang spesifik muncul sebagai strategi kompetitif. Itu menguntungkan untuk pengembangan produk yang memadai dan memuaskan bagi individu yang berbeda. Mengenai konteks mode, produk pakaian memberikan saluran makna dan identifikasi subyektif tingkat emosional. Mempertimbangkan kontak langsung antara pakaian dan pengguna, informasi tentang antropometrik biomekanik dan ergonomis sangat relevan untuk pengembangan pemodelan yang disesuaikan dengan kebutuhan berbeda dari segmen pengguna yang berbedaa. Penelitian ini menggunakan studi literature dalam memecahkan masalah dalam investigasi tentang perkembangan manufacture di bidang pertekstilan.
\end{abstract}

Kata kunci-Fashion; Ergonomi; Persepsi Mode

\begin{abstract}
The purpose of this research is to investigate the problems regarding the existence of fashion fashions which have increasingly increased in its segmentation lately. The increasing number of consumers and users who are looking for different products and in accordance with their needs and expectations has an impact on the design stage as well as on the consistent manufacturing process. Thus understanding the specific segmentation of consumers and users arises as a competitive strategy. It is advantageous for developing products that are adequate and satisfying for different individuals. Regarding the context of fashion, clothing products provide channels of meaning and subjective identification of emotional levels. Considering direct contact between clothes and users, information about biomechanical and ergonomic anthropometrics is very relevant for the development of modeling that is tailored to the different needs of different user segments. This research uses literature study in solving problems in the investigation of manufacturing developments in the textile field.
\end{abstract}

Keywords-Fashion,Ergonomic, Mode Perseption

\section{PENDAHULUAN}

Mode dari masa ke masa selalu mengalami perkembangan seiring dengan peningkatan teknologi pada infrastruktur khususnya dalam teknologi pertekstilan. Walaupun revolusi industri di abad 20 telah lama berlalu permasalahan tentang eksistensi masyarakat dalam berpakain sering muncul tiap dekade berbanding lurus dengan peningkatan ekonomi suatu wilayah dan pendapatan 
masyarakat di dalamnya. Peningkatan jumlah konsumen dan pengguna yang mencari produk yang variatif dan sesuai dengan kebutuhan dan harapan mereka akan berdampak pada tahap desain serta pada proses manufaktur yang dilakukan dalam proses pabrikasi. Dengan demikian pemahaman pola segmentasi tertentu dari konsumen muncul sebagai strategi kompetitif yang menguntungkan sebagai pengembangan produk yang memadai dan memuaskan bagi individu atau komunitas urban yang memiliki pola pikir dan mindset berbeda. Menurut (Schumacher, 2017) konsumen setidaknya harus mampu mempertimbangkan proses integrasi langsung pakaian yang dikenakan dengan kulit dan topografi tubuh, hal ini dipertegas dengan menampilkan kegunaannya pakaian mampu membuahkan penilaian yang melekat pada persepsi terkait aspek utilitas , selera, kenyamanan,dan kepuasan mengenai kebutuhan subjektif individu itu sendiri terutama yang terjadi pada masyarakat urban di perkotaan dengan mobilitas tinggi.

Dari prinsip ini, (Martins, 2012) menyatakan desain ergonomis menyediakan suatu tools yang ketika diterapkan selama tahap manufaktur pakaian, keadaan ini secara lebih jauh dapat mengarahkan karakteristik produk yang dirancang demi keselamatan, efisiensi dan kenyamanan konsumen. Berbagai cara dilakukan untuk memahami kompleksitas integrasi tubuh dengan kecocokan pakaian telah banyak dilakukan riset hingga saat ini, studi tentang anatomi dan gerakan tubuh dikemukakan oleh (Wu, Chao, \& Luximon, 2018). Dalam penelitiannnya dibahas tentang pentingnya menelusuri memahami rencana pola keseimbangan seluruh tubuh serta gerakan yang mempengaruhi pola gerakan tubuh manusia seperti fleksi, ekstensi, dan lainnya. Dengan cara ini, interaksi multi talent dan interdisipliner antara proyek manufaktur pakaian jadi dan desain ergonomis memiliki kontribusi yang besar pada kemajuan dan resolusi proyek pengembangan produksi pakaian jadi dalam jangka panjang. Pemahaman tentang konsep utilitas, kenyamanan, dan ergonomi yang spesifik untuk komunitas tertentu diperlukan dalam menghasilkan desain pola busana yang bertujuan memenuhi harapan dan persyaratan produktivitas manufactur pakaian jadi di masa mendatang. Metamorfosis Mode fashion Sepanjang beberapa dekade ini berbanding lurus dengan evolusi masyarakat, perkembangan fashion berkontribusi dengan identifikasi eksistensi peran sosial dan identitas subjek dengan penggunaan hierarkis berbagai pakaian dan aksesori. Karakter simbolisnya merupakan cerminan dari aspirasi masyarakat secara subyektif dan budaya mode pada periode tertentu yang selalu berubah. Pada giliranny manufacture di bidang mode secara signifikan merefleksikan aspek fisik dan konstruktif dari produk-produk fashion, terutama pakaian yang memiliki pola perkembangan kehidupan manusia dari (Tamagawa, 1970). Sehubungan dengan aspek simbolik dan prestige,maka tampilan fisik dan material dari pakaian dapat disadari terdapat adanya ketidakterbatasan kontekstual transformasi mode yang mengekspresikan konteks sosial, budaya dan teknologi pada periode tertentu. Secara umum, pakaian telah melalui proses penyederhanaan, terutama dari dekade 1800 sejak revolusi industri pertama.

Fenomena perkembangan dunia mode dan manufacture ini terutama disebabkan oleh teknologi industri baru yang semakin lama semakin berkembang. Timgkat permintaan produk yang lebih tinggi akan adaptasi ke proses manufaktur baru. Sebagai contoh,perkembangan revolusi mode pakaian wanita yang dipimpin oleh desainer Prancis Paul Poiret pada awal abad kedua puluh dapat disebutkan bahwa berkat pencipta mode, pakaian wanita disederhanakan menjadi lebih ringan, sehingga memudahkan gerakan tubuh wanita terkait dengan aktivitasnya. Inovasi mode terpecah beberapa aliran mode menjadi misalnya menciptakan pola struktur kaku dari korset yang membuat tekanan pada perut wanita untuk menciptakan dan menentukan pinggang yang ramping, payudara yang menonjol dan postur yang lurus. Para perancang busana juga banyak mendukung eksistensi manufacture dengan mengembangkan desain mode Stylist menciptakan siluet yang lebih ringan, garis leher yang lebih dalam (terutama model "V"), bahu yang terlihat memiliki bentuk yang luas, dan variasi pemodelan lainnyayang lebih kreatif. Secara umum, perkembangan sejarah dunia tak pernah luput dari perkembangan mode dunia. Berbagai praktik sosial, budaya, dan profesionalimse telah berkontribusi tidak terfokus hanya pada pola efisien hal yang terkait dengan kebutuhan individu dan tugas sehari-hari mereka. Tren ini berkembang secara logis dengan pengembangan industri secara berkelanjutan membuahkan produksi masal skala besar antara tahun 1950 dan 1960 bertepatan dengan revolusi industri 
pertama. Sesuai dengan perkembangan jaman fashion telah menjadi lebih luwes dan demokratis. Oleh karena itu konsumen sebagai pengguna mulai merasakan dengan lebih banyak relevansi yang mendukung perusahaan-perusahaan di sektor manufacture ini. Fase perkembangan industri manufaktur di bidang Garmen yang berorientasi secara massal memiliki ciri khas khusus oleh mansyarakat luas kemudian yang kemudian dikenal di Perancis sebagai pret-à-porter, dan di Amerika Serikat sebagai pakaian siap pakai atau disebut garmen manufacture. Proses penciptaan produk akan tergantung pada eksistensi permintaan dan penawaran yang telah lama konsisten akan berbanding lurus dengan realitas ekonomi suatu negara, perbedaan budaya dan peningkatan demografis apalagi pengembangan pola segmentasi saat pascaperang dunia ke 2 yang menimbulkan depresi di daratan Eropa kala itu. Menurut (Nakayama, Martins, \& Martins, 2016) ada intesitas kebutuhan untuk eksistensi dan kuantitas produk yang lebih banyak secara simultan. Secara lebih jauh sistem produksi yang mengalir cepat lambat laun mulai dipraktikkan berdasarkan karakteristik pemanfaatan industri baru yang disesuaikan dengan peningkatan permintaan produk garmen di seluruh dunia apalagi di Britania sebagai acuan dari manufaktur tekstil dunia. Sistem pola pemikiran industri baru telah mampu mempromosikan transformasi hebat dalam dengan dukungan proses kreatif dan pengembangan desain pada produk fashion yang diproduksi secara massal. Permintaan suatu produk meningkat secara signifikan disebabkan oleh tumbuhnya kelompok sosial baru yang memiliki daya beli lebih tinggi dan bentuk konsumsi baru terbentuk dengan munculnya mekanisasi industri secara tepat guna otomatisasi pada produksi massal. Akibatnya, sistem ini berkembang dengan cepat dan melalui jalur perdagangan internasional telah mampu disebarluaskan melalui beberapa wilayah di dunia, dukungan yang kuat penguatan industri tekstil dan pakaian jadi.

Tahapan desain dan perencanaan produksi pakaian jadi semakin meningkat sehubungan dengan berkembangnya teknologi desain dan peralatan produksi tekstil di masa kini. Perkembangan ini akan menjadi sesuatu yang lebih sensitif jika dihubungkan dengan gerakan sosial budaya dan pola konsumsi masyarakat di masa kini maupun di masa yang akan datang. Konsumsi hedonistik dalam kondisi masyarakat yang semakin tinggi pola komsumsinya berbanding lurus dengan tingkat pendapatan masyarakat dari waktu ke waktu. Secara intensif keadaan ini akan mendukung terutama diperkuat oleh representasi elemen estetika dan simbolisasi segmentasi dari produk-produk fashion yang dilahirkan ke pasar. Konsekuensinya, industri manufaktur di bidang tekstil harus bersifat terbuka terhadap kekuatan persepsi dan keinginan masyarakat di masa kini yang semakin terfokus pada simbolisasi gaya hidup. Pada pemikiran paradigm baru kemungkinan akan menimbulkan ekspresi kemunculan krisis identitas di tiap komunitas terutama para Urban yang memiliki life style dan pola hidup yang serba dinamis. Remaja adalah segmen konsumen yang secara signifikan mempengaruhi eksistensi pedoman pengembangan proses manufaktur beberapa produk fashion selama beberapa dekade terakhir yang merupakan hasil konsolidasi sistem industri berkelanjutan dalam revolusi industri 4.0 hingga akhir akhir ini (Neves, Brigatto, \& Paschoarelli, 2015).

(Kaljun \& Dolak, 2011) Menyatakan pengembangan ide postmodernisme pada segmentasi pasar menjadi lebih kompleks seiring dengan perkembangan jaman dan hingga saat ini menjadi sesuatu yang tidak homogen. Kecenderungan konsumsi masyarakat modern akan mendorong pola industri dengan jalan membagi pola pengembangan pasar menjadi beberapa tingkatan segmen yang lebih kecil yang mampu diidentifikasi secara lebih mendasar oleh kebutuhan diperkuat oleh harapan individu yang berbeda dari waktu ke waktu. Dalam tinjauan skenario ini, konsumen dianggap sebagai faktor penentu terbesar dalam pengembangan produk fashion. Seperti pada periode sebelumnya keinginan dan harapan konsumen secara signifikan mempengaruhi ukuran produk sejalan dengan pertimbangan aspek estetika, fisik, praktis, dan fungsional dalam kehidupan masyarakat. Faktor penentu ini pada gilirannya mulai banyak menentukan metodologi konstruktif baru untuk produksi garmen hingga saat ini. Aspek-aspek pola pemilihan busana dalam kehidupan masyarakat menjadi lebih menonjol terutama karena produk yang dihasilkan lebih fokus pada ketegasan produk walaupun hal ini terdapat batasan segmentasi di dalamnya. Target audiens mulai dianalisis dan dipertimbangkan ketika perkembangan teknologi informasi mulai muncul belakangan ini terlebih terutama ketika industri 
produksi pakaian mulai menyadari bahwa untuk meningkatkan produksi dan penjualan diperlukan stimulant untuk merangsang timgkat konsumsi masyarakat yang semakin berkembang sehingga lebih efektif dan berkelanjutan. Membeli dan memiliki suatu produk fashion adalah suatu tindakan positif yang mampu menafsirkan subjektivitas individu melalui elemen non-verbal, di dalammnya direfleksikan menurut pola pikir masyarakat modern bagaimana subjek pemakai fashion bagi kalangan urban. Dalam konteks industrialisasi beberapa pengetahuan ergonomis muncul pada pasca perang Dunia II yang mulai memasukkan unsur konsumtif sehingga proses manufaktur terus berjalan berkesinambungan.

Dengan produksi industri, pola pakaian dari ukuran dan ukuran / ukuran mulai menjadi penting untuk mencakup standar dimensi beberapa variasi individu. Saat mengetahui pengguna dengan baik, mengenali kebutuhan, kemampuan, dan keterbatasan mereka, dimungkinkan untuk mengidentifikasi terlebih dahulu terjadinya kecelakaan, kerusakan kesehatan, dan ketidaknyamanan. Akibatnya, individu secara bertahap dilihat sebagai pengguna dan bukan hanya sebagai konsumen belaka. Bersamaan dengan ini, segmentasi pasar mulai menawarkan variasi dalam manfaat fungsional serta lebih banyak perhatian terhadap kebutuhan hedonistik. Terutama dengan munculnya postmodernisme, para peneliti dengan pengguna dan konsumen mulai mengekstrapolasi aspek pemasaran dan periklanan. Manipulasi gambar yang direalisasikan oleh media, terutama setelah pertengahan 1950-an, tidak lagi memadai mengingat luasnya produk yang membentuk pasar. Menurut (Lee, Eom, \& Lee, 2016) dalam masyarakat pasca industri, aspek-aspek yang mencolok dari produk tidak lagi memadai bagi pengguna atau konsumen, menjadi pengalaman dan emosi, kedua aspek yang sangat penting bagi kualitas suatu produk. Mengenai konteks mode, produk pakaian memberikan saluran makna dan identifikasi subyektif tingkat emosional. Selain elemen dan komposisi simbolis dan estetika, ia memberikan alat yang tidak bisa dibedakan untuk promosi negara afektif kepada individu. Dengan demikian, fungsi dasar pakaian memperkirakan fungsi berpakaian dan menutupi tubuh dan berhubungan dengan kondisi sosial dari subjektivitas dan konstruksi identitas

(R. C. Tzou \& Lu, 2009) Memberikan pernyataan dalam penelitiannya bahwa kontak langsung dengan foto tubuh dan kulit, produk fesyen menghasilkan penilaian nilai yang dihasilkan dari persepsi aspek kegunaan, kesenangan, kenyamanan, kenikmatan, dan kepuasan kebutuhan individu. Dengan cara ini, karakteristik fisik dan struktural pakaian yang mengkonfigurasi produk fesyen ini merangsang evaluasi positif pengguna mengenai produk tertentu. Dalam proses ini, karakteristik interdisipliner ergonomi dipersepsikan sebagai faktor yang membantu dalam mediasi antara tubuh dan pakaian, begitu ilmu ini dapat menawarkan alat konstruktif yang mungkin dapat memberikan keamanan, kenyamanan dan kesehatan bagi pengguna.

\section{METODE PENELITIAN}

Aspek Desain dan Kegunaan Ergonomis

(Ahmed Elnashar, 2018) berdasarkan penelitiannya Memberikan pertimbangan bahwa kontak langsung antara pakaian dan pengguna, informasi tentang antropometrik biomekanik dan ergonomis sangat relevan untuk pengembangan pemodelan yang disesuaikan dengan kebutuhan yang berbeda dari segmen pengguna yang berbeda. Mengidentifikasi aspek-aspek ini, dimungkinkan untuk mengembangkan produk yang memuaskan, aman dan nyaman. Menurut (Kim \& Na, 2014) pakaian itu, karena kontak dengan pengguna, bertindak seperti perpanjangan tubuh seperti "kulit kedua", yang, pada gilirannya, sangat penting untuk mengoptimalkan antarmuka antara produk dan pengguna untuk menghindari ketidaknyamanan. Pemodelan adalah proses yang dimulai dari pengamatan tubuh dan pemetaannya, dan berakhir dengan uji ganti pada tubuh nyata. Oleh karena itu, untuk pengembangan pemodelan yang memadai diperlukan untuk mengetahui anatomi manusia serta fungsi tubuh. Pada titik ini, dalam penelitiannya (Pagnan \& Câmara, 2012) karakteristik spesifik individu harus diperhatikan dan dieksploitasi untuk mendapatkan data yang konsisten untuk pengembangan produk yang sesuai dan dengan kualitas. 
Penting juga untuk memahami atau memperkirakan preferensi dan tanggapan pengguna mengenai produk yang akan dielaborasi. Penggunaan antropometrik, melalui penerapan metode ilmiah pengukuran tubuh, sesuai untuk mengidentifikasi perbedaan antara individu dan kelompok sosial.

Tujuan dari aplikasi ini bertujuan untuk memperoleh informasi yang relevan untuk membantu desain arsitektur, perencanaan urbanisme, proyek teknik, dan tentu saja, desain. Dalam perspektif mode, semua artikulasi tubuh yang melibatkan atau mempertahankan kontak langsung dengan pakaian harus dianalisis untuk menciptakan produk dengan kualitas estetika dan ergonomi. Mengenai pakaian ahli pertekstilan (R.-C. Tzou \& Lu, 2009) menyatakan bahwa pendekatan antropometri menyediakan bagi para perancang dua sistem pengukuran tubuh: Statis atau Struktural; dan Dinamis atau Fungsional. Yang pertama terkait terutama dengan variasi tubuh individu, dan yang kedua dengan aspek biomekanik berbeda yang terkait dengan gerakan yang berbeda dan tugas sehari-hari. Pemodelan konveksi terutama menggunakan data statistik pengguna seperti lingkar pinggang, pinggul dan leher; panjang tubuh atau lengan; dan lain-lain. Data ini memengaruhi dimensi pakaian. Bersamaan dengan ini, kontribusi khusus dari segmen pengguna tertentu membantu memandu gambar atau bentuk yang benar dari beberapa potong pakaian yang harus memadai untuk kebutuhan dan harapan yang spesifik dan berbeda. Pengguna wanita atau pria, lansia dan obesitas adalah beberapa segmen yang dapat menggambarkan kenyataan ini.

Menurut (Debastiani e Silva, Bischof, de Oliveira, Rodrigues, \& Nickel, 2019) setiap wilayah tubuh harus dianalisis untuk memberikan informasi yang benar tentang bagaimana sepotong pakaian akan bekerja dalam kaitannya dengan gerakan fisik. Lengan, kaki, pinggul, dan kepala, misalnya, membuat beberapa gerakan yang mungkin bertentangan dengan karakteristik tertentu yang ada dalam pakaian tertentu, seperti lengan baju ketat / lengan baju atau kerah, cat longgar, dan lain-lain. Untuk pekerjaan bersama ini, beberapa aspek mengenai biomekanik dan artikulasi sendi harus diidentifikasi, seperti: ekstensi, fleksi, adduksi dan abduksi; rotasi; dan circumduction. Dengan demikian, proses pakaian harus menyatukan anatomi, gerakan dan produk itu sendiri untuk memenuhi kebutuhan fisik dan anatomi pengguna, mencapai kualitas berpakaian yang ideal melalui fungsi dan kenyamanan.

Dengan variabel-variabel ini dimungkinkan untuk membuat profil antropometrik pengguna setelah standar kegunaan yang berbeda dapat diidentifikasi. Para pengguna lanjut usia, misalnya, membutuhkan perhatian terkait dengan kecacatan yang melekat pada proses penuaan. Dengan hilangnya keseimbangan, kekuatan otot, dan batasan penglihatan secara bertahap, beberapa aktivitas berpakaian mungkin dilakukan dengan sedikit kesulitan, seperti pakaian, untuk menutup tombol, mengenakan sepatu dan kaus kaki, dan lainnya. Contoh-contoh ini membawa beberapa pembatasan terutama mengenai mobilitas, tetapi penting untuk memperhatikan bahwa kekhasan tubuh lain dapat mempengaruhi kegunaan pakaian. Menurut (Montano Murillo, Subramanian, \& Plasencia, 2017) dalam penelitiannya tentang ergonomis pakaian wanita usia menengah, misalnya, yang mengalami masalah biopsikososial menopause, sadar akan perubahan tubuh mereka yang dihasilkan dari tahap kehidupan ini. Tampaknya sebagian besar perubahan ini dievaluasi secara negatif oleh wanita paruh baya. Ia juga mencatat bahwa, karena kenyataan ini, kebanyakan dari mereka mengidentifikasi diri mereka tidak nyaman.

Perubahan ukuran perut, pinggang dan pinggul adalah beberapa area yang karena peningkatan adipositas dapat menyebabkan ketidaknyamanan dan ketidakpuasan. Karena ini, pakaian telah dilihat sebagai alat untuk memanipulasi aspek fisik yang mengganggu para wanita ini. Pinggang dan perut misalnya, adalah area yang paling membutuhkan gangguan pakaian karena kapasitas beberapa potong pakaian petak umpet atau menyamarkan beberapa "ketidaksempurnaan tubuh". Dalam pengertian ini menurut (Suhag \& Singh, 2015) dapat diperhatikan bahwa ada variasi tubuh tertentu yang penting untuk dipertimbangkan mengenai karakteristik pakaian untuk segmen ini. Pertimbangan tentang biomekanik bahkan dapat digeneralisasi, namun perbedaan antropometrik dan subyektif secara signifikan mempengaruhi penilaian produk fesyen terutama yang berkaitan dengan aspek kegunaan. Aspek lain yang harus dipertimbangkan dalam keputusan proyek pakaian adalah kegiatan dan tugas yang dilakukan oleh 
pengguna. Kekhasan tindakan ini dapat menghadirkan perbedaan dalam dinamika tubuh, terutama jika diamati aktivitas profesional dan praktik olahraga

\section{HASIL DAN PEMBAHASAN}

Selama beberapa tahun terakhir, olahraga telah memengaruhi inovasi teknologi dalam bidang tekstil dan pakaian. Berfokus pada efisiensi, kenyamanan, keselamatan, serta kinerja atlet, industri olahraga telah berinvestasi dalam pengembangan teknologi baru. Fakta ini dapat diamati dalam peningkatan merek olahraga dan semakin banyak penelitian yang membawa masalah tentang alam semesta ini. Mengenai pakaian profesional, dinamika kegiatan sehari-hari harus mengarahkan desain produk. Lingkungan eksternal, kinerja biomekanik, karakteristik tugas dan aspek antropometrik pengguna dapat memberikan informasi tegas yang penting untuk efisiensi pakaian selama latihan profesional. Perspektif inklusi sosial juga telah mempengaruhi jagad mode. Tujuannya adalah untuk menciptakan pakaian dengan elemen estetika dan bentuk yang memadai yang dapat membantu partisipasi individu dalam lingkungan sosial-budaya tertentu tanpa membahayakan kesehatan dan kesejahteraan mereka. Pengamatan tubuh dan kegiatan pengguna serta keterbatasan fisik mereka sangat penting untuk mengidentifikasi kebutuhan dan harapan mereka. Secara umum, pemahaman tentang mekanisme manusia, gerakan sukarela dan tidak sukarela serta perilaku psikologis pengguna tertentu relatif penting untuk proyek pakaian. Oleh karena itu, pengetahuan ergonomi penting untuk memandu proyek semacam ini dengan benar, begitu sains ini terkait dengan tugas sehari-hari dan lingkungan orang.

(Silva, Pereira, Ferreira, \& Silva, 2018) Menyatakan bahwa ergonomi berfokus pada manusia, mengidentifikasi semua jenis keterampilan, kecacatan, aspek fisik dan kognitif, perspektif budaya dan sosial, dan aspek-aspek lain mengenai dinamika tubuh. Mengenai pakaian, sebagaimana telah diamati, fungsinya melampaui dasar-dasar dekorasi dan penutup tubuh. Pakaian melibatkan demi kesehatan mental dan fisik sekaligus dapat menjamin kenyamanan dan keamanan bagi pengguna serta merangsang persepsi subjektif. Dalam hal ini, kerja bersama antara pemodelan ergonomis, tubuh, estetika dan bahan baku (tekstil) secara signifikan penting untuk ketegasan produk pakaian.

\section{SIMPULAN}

Konsumen semakin mencari produk-produk fesyen yang menghadirkan kualitas fisik yang unik seperti kegunaan. Dalam perspektif ini, inovasi dan strategi diferensiasi sangat penting untuk mendukung hubungan antara produk dan pengguna, serta positioning merek di depan para pesaing. Untuk ini, pemahaman segmen tertentu dari konsumen dan pengguna muncul sebagai strategi kompetitif yang menguntungkan produk fashion yang memadai dan memuaskan untuk kebutuhan dan keinginan spesifik. Oleh karena itu, pemahaman tentang faktor-faktor yang dapat mempengaruhi akuisisi dan penggunaan beberapa potong pakaian menjadi penting untuk memandu proses desain produk fashion. Karena logika ini, karakteristik biofisik, antropometrik, dan sosial yang spesifik untuk setiap segmen minat harus selalu dipertimbangkan.

Dalam proses kreatif. Variabel-variabel ini, ketika bekerja dengan baik dan menerapkan menambah nilai pada produk melalui keterlibatan dan integritas dalam interrelasi aksi-pengguna / tugas-pakaian. Selain itu, mengingat hubungan yang erat antara pakaian dan tubuh, produk fashion menghasilkan nilai penilaian yang melekat pada persepsi beberapa aspek seperti kegunaan, kesenangan, kenyamanan, kesenangan dan kepuasan kebutuhan individu dan subyektif. Dalam konteks ini, kualitas struktural dan fisik (seperti kenyamanan sentuhan dan termal) yang mendukung pakaian secara langsung mempengaruhi evaluasi positif produk ini. Dalam proses ini, antropometri dan ergonomi (dan karakteristik interdisiplinernya) adalah pengetahuan yang membantu kerja asertif mengenai hubungan tubuh dan pakaian, setelah pemahaman ini menawarkan beberapa alat yang bila digunakan dengan tepat, dapat meningkatkan 
keselamatan, kesehatan, dan kenyamanan bagi pengguna. Secara paralel, elemen estetika dan simbolis dari produk fashion merangsang persepsi emosi pengguna melalui komposisi plastiknya dengan mempromosikan kesenangan estetika dan, akibatnya, menghasilkan nilai penilaian positif di depan suatu produk.

\section{DAFTAR PUSTAKA}

Ahmed Elnashar, E. (2018). Trends in Mathematical Stitchless Model of Volume Fitting Stretch for Design of Sport Bra. Trends in Textile Engineering \& Fashion Technology, 2(1). https://doi.org/10.31031/tteft.2018.02.000528

Debastiani e Silva, L., Bischof, B. M., de Oliveira, R. P. C., Rodrigues, R. S., \& Nickel, E. M. (2019). Work Macroergonomics Analysis (AMT Method): Identification of Ergonomic Demands in Sewing Laboratory. Advances in Intelligent Systems and Computing, 821, 521529. https://doi.org/10.1007/978-3-319-96080-7_63

Kaljun, J., \& Dol ak, B. (2011). ERGONOMIC DESIGN RECOMMENDATIONS BASED ON AN ACTUAL CHAINSAW DESIGN. The South African Journal of Industrial Engineering, 23(2). https://doi.org/10.7166/23-2-342

Kim, H., \& Na, H. (2014). A Study on Ergonomic Fashion Design - Focused on Body Conscious Active Sportswear -. Fashion \& Textile Research Journal, 16(3), 434-445. https://doi.org/10.5805/sfti.2014.16.3.434

Lee, H., Eom, R., \& Lee, Y. (2016). Development of Ergonomic Leg Guard for Baseball Catchers through 3D Modeling and Printing. Fashion Business, 20(3), 17-29. https://doi.org/10.12940/jfb.2016.20.3.17

Martins, S. B. (2012). Ergonomics and fashion: The OIKOS methodology for usability and comfort evaluation in clothing and fashion. Work, 41(SUPPL.1), 6059-6067. https://doi.org/10.3233/WOR-2012-1061-6059

Montano Murillo, R. A., Subramanian, S., \& Plasencia, D. M. (2017). Erg-O: Ergonomic optimization of immersive virtual environments. UIST 2017 - Proceedings of the 30th Annual ACM Symposium on User Interface Software and Technology, 759-771. https://doi.org/10.1145/3126594.3126605

Nakayama, G., Martins, S., \& Martins, L. B. (2016). The perspective of Ergonomics teaching in fashion design courses in Brazil. SHO2016: INTERNATIONAL SYMPOSIUM ON OCCUPATIONAL SAFETY AND HYGIENE, 221-223.

Neves, É. P. das, Brigatto, A. C., \& Paschoarelli, L. C. (2015). Fashion and Ergonomic Design: Aspects that Influence the Perception of Clothing Usability. Procedia Manufacturing, 3, 6133-6139. https://doi.org/10.1016/j.promfg.2015.07.769

Pagnan, A. S., \& Câmara, J. J. D. (2012). Ergonomics analysis of the productive environment of fashion clothing firm in Belo Horizonte- MG. Work, 41(SUPPL.1), 1261-1267. https://doi.org/10.3233/WOR-2012-0311-1261

Schumacher, P. (2017). Tectonism in architecture, design and fashion: Innovations in digital fabrication as stylistic drivers. Architectural Design, 87(6), 106-113. https://doi.org/10.1002/ad.2245

Silva, T., Pereira, T., Ferreira, L. P., \& Silva, F. J. G. (2018). Improving the Multi-Brand Channel Distribution of a Fashion Retailer. Procedia Manufacturing, 17, 655-662. https://doi.org/10.1016/j.promfg.2018.10.114

Suhag, N., \& Singh, S. (2015). Types of Chromism \&amp; Its Applications in Fashion \&amp; Textile Designing. International Journal of Enhanced Research in Science Technology \& Engineering, 4(8), 2319-7463.

Tamagawa, C. (1970). The Ergonomic Survey and Fashion Trend of Underclothes. Journal of the Textile Machinery of Japan - Proceedings -, 23(9), P633-P637. https://doi.org/10.4188/transjtmsj1965a.23.p633

Tzou, R.-C., \& Lu, H.-P. (2009). Exploring the emotional, aesthetic, and ergonomic facets of 
innovative prod...: EBSCOhost. Behaviour \& Information Technology, 28(4), 311-322.

Tzou, R. C., \& Lu, H. P. (2009). Exploring the emotional, aesthetic, and ergonomic facets of innovative product on fashion technology acceptance model. Behaviour and Information Technology, 28(4), 311-322. https://doi.org/10.1080/01449290701763454

Wu, H., Chao, H., \& Luximon, A. (2018). Fashion education innovations based on ergonomic design. Advances in Intelligent Systems and Computing, 602, 365-371. https://doi.org/10.1007/978-3-319-60825-9_39 